\title{
Badania naprężeń własnych w powłokach metalowych natryskiwanych na podłoże ceramiki $\mathrm{Al}_{2} \mathrm{O}_{3}$
}

\section{Determination of residual stresses in metal coatings thermally sprayed on $\mathrm{Al}_{2} \mathrm{O}_{3}$ substrate}

\section{Streszczenie}

W pracy przedstawiono wyniki badań i analizy naprężeń własnych $\mathrm{w}$ powłokach tytanowych i miedzianych nanoszonych na podłoże ceramiki $\mathrm{Al}_{2} \mathrm{O}_{3}$ metodą natryskiwania naddźwiękowego HVOF. Naprężenia wyznaczano w sposób eksperymentalny, analityczny oraz numeryczny z wykorzystaniem takich narzędzi jak metoda rentgenowska (X-ray), pomiary krzywizny wygięcia, metoda interferometrii siatkowej oraz numeryczne modelowanie (MES). Dokonano porównania naprężeń w natryskiwanych powłokach $\mathrm{Ti}$ i Cu. Wszystkie metody wykazały występowanie naprężeń rozciągających w powłoce o wartościach zróżnicowanych zależnych od metody badań.

Słowa kluczowe: naprężenia własne, natryskiwanie termiczne, metody pomiaru

\begin{abstract}
The paper presents the results of research and analysis of residual stresses in titanium and copper coatings deposited onto $\mathrm{Al}_{2} \mathrm{O}_{3}$ substrate using HVOF thermal spraying method. Residual stresses were determined in an experimental way, analytical and numerical using

X-ray method, sample curvature measurement, grating interferometry method and numerical modeling (FEM). A comparison of the stresses obtained in the $\mathrm{Ti}$ and $\mathrm{Cu}$ sprayed coatings has been performed. All the methods showed the presence of tensile stresses in the coating of different magnitude depending on the applied method.
\end{abstract}

Keywords: Residual stresses, thermal spraying, measurement methods

\section{Wstęp}

Procesy natryskiwania termicznego należą do jednych z najbardziej uniwersalnych metod modyfikacji powierzchni [1]. W szczególności zastosowanie tej technologii do wytwarzania powłok metalowych na podłożu ceramiki konstrukcyjnej (m.in. $\mathrm{Al}_{2} \mathrm{O}_{3}, \mathrm{ZrO}_{2}$, AIN i inne) może przynieść szereg korzyści. Zaawansowana ceramika konstrukcyjna jest coraz szerzej stosowana $w$ wielu gałęziach przemysłu np. optoelektronice, przemyśle jądrowym, energetycznym, półprzewodnikowym czy w technice wysokiej próżni. W wielu aplikacjach ceramika musi być łączona z metalami, co w przypadku tak zróżnicowanej pod względem właściwości pary materiałów wymaga odpowiedniego przygotowania powierzchni ceramicznej, najczęściej poprzez jej metalizowanie za pomocą długotrwałych procesów termicznych [2]. Możliwość uzyskania powłoki metalizacyjnej na podłożu ceramicznych w procesie natryskiwania termicznego może przynieść szereg korzyści takich jak znaczące przyspieszenie wytwarzania powłok metalizacyjnych oraz obniżenie kosztów przy znacznie mniejszym stopniu skomplikowania całego procesu.

Tak jak przy samym spajaniu materiałów ceramicznych z metalami, tak i w procesie natryskiwania materiałów metalowych na podłoże ceramiczne mamy do czynienia ze znaczącą różnicą właściwości cieplno-fizycznych oraz mechanicznych obu materiałów, które prowadzić będą do generowania pewnego stanu naprężeń własnych w układzie powłoka/ podłoże [3]. Wielkość i rozkład tych naprężeń może wpływać na wytrzymałość złącza jeśli powłoka pracować będzie w warunkach zróżnicowanych obciążeń eksploatacyjnych. W szczególności, niekorzystny rozkład naprężeń własnych powstały po na granicy powłoka/podłoże lub w samej powłoce po procesie natryskiwania może być przyczyną szybszej degradacji czy delaminacji powłoki a nawet do powstania pęknięć w powłoce, które doprowadzą do skrócenia trwałości powłoki [4]. Dlatego też stan naprężeń własnych w natryskiwanych na podłoże ceramiczne powłokach metalowych stanowi jedno z ważniejszych zagadnień badawczych, które wpływa na trwałość eksploatacyjną powłoki.

W niniejszej pracy przedstawiono wyniki badań oraz analizy naprężeń własnych w powłokach tytanowych i miedzianych nanoszonych na podłoże ceramiki Al203 metodą natryskiwania płomieniowego naddźwiękowego (HVOF). Naprężenia wyznaczano w sposób eksperymentalny, analityczny oraz numeryczny z wykorzystaniem takich narzędzi jak metoda rentgenowska (X-ray), pomiary krzywizny wygięcia, metoda interferometrii siatkowej (IS) oraz modelowanie

Drhab. inż. Dariusz Golański, prof PW; prof. dr hab. inż. Małgorzata Kujawińska; dr hab. inż. Tomasz Chmielewski, prof. PW; mgr inż. Grzegorz Dymny; dr inż. Jolanta Zimmerman - Politechnika Warszawska. 
numeryczne metodą elementów skończonych (MES) w celu porównania i weryfikacji wyników z różnych technik badawczych.

\section{Materiały do badań}

Badaniom poddano próbki z powłokami tytanowymi oraz miedzianymi, które nanoszono na podłoże ceramiki $\mathrm{Al}_{2} \mathrm{O}_{3}$ (płytki o wymiarach 20x30x0,6 mm) w procesie natryskiwania cieplnego metodą HVOF. Materiał powłokowy w formie drobnoziarnistego (o średnicy ok. $50 \mu \mathrm{m}$ ) czystego proszku $\mathrm{Ti}$ i Cu natryskiwano na podłoże $\mathrm{Al}_{2} \mathrm{O}_{3}$ za pomocą systemu HV-50 z palnikiem JP-5000. Otrzymane powłoki były ciągłe i jednorodne bez widocznych śladów pęknięć czy odwarstwienia. W jednym procesie wykonano natryskiwanie serii pięciu próbek dla każdego badanego materiału powłokowego uzyskując średnią grubość powłoki na poziomie 0,119 $\mathrm{mm}$ oraz $0,085 \mathrm{~mm}$ odpowiednio dla powłoki Ti oraz $\mathrm{Cu}$.

\section{Badania naprężeń własnych w powłokach}

Przeprowadzono badania naprężeń własnych w wytworzonych powłokach za pomocą trzech metod badawczych: rentgenowskiej, interferometrii siatkowej oraz poprzez pomiary krzywizny wygięcia próbek, a także przeprowadzono modelowanie numeryczne naprężeń własnych w modelach odzwierciedlających badane próbki.

\section{Metoda rentgenowska (X-ray)}

Przeprowadzono badania naprężeń własnych w natryskiwanych powłokach tytanowych i miedzianych otrzymanych w wyniku natryskiwania na podłoże ceramiki $\mathrm{Al}_{2} \mathrm{O}_{3}$ metoda płomieniową naddźwiękową (HVOF). Próbki miały kształt prostokątna $20 \times 30 \times 0,6 \mathrm{~mm}$, a średnie grubości poszczególnych powłok wynosiły: 0,119 mm dla Ti i 0,085 mm dla $\mathrm{Cu}$. Próbki zostały zbadane w celu wyznaczenia charakterystyki naprężeniowej powłok w ich warstwie przypowierzchniowej o grubości do kilkunastu mikrometrów, na obszarze o powierzchni ok. $2 \mathrm{~mm} 2$ zlokalizowanym w strefie środkowej powłoki.

Pomiar naprężeń własnych poprzedzono rentgenowską analizą fazową. Wszystkie pomiary wykonano za pomocą dyfraktometru D8 Discover (firmy Bruker) wyposażonego w detektor pozycyjnie czuły LynxEye o kątowym zakresie detekcji równym $2,6^{\circ}$ oraz optykę wiązki pierwotnej PolyCap z kolimatorem typu pinhole o aperturze 1,0 mm. Zastosowano promieniowanie filtrowane serii CoKa $(\lambda=1,79026$ $\AA$ ). Naprężenia własne wyznaczono w oparciu o klasyczną metodę $\sin 2 \psi[5]$. O wyborze danych refleksów dyfrakcyjnych dla przeprowadzenia pomiaru i analizy stanu naprężeń własnych decydowało położenie pików względem refleksów od materiału podłoża $\left(\mathrm{Al}_{2} \mathrm{O}_{3}\right)$, na które nie mogły one zachodzić, szczególnie wobec braku znajomości tekstury krystalograficznej wykorzystanego $\mathrm{Al}_{2} \mathrm{O}_{3}$.

Do pomiarów naprężeń własnych w powłoce $\mathrm{Cu}$ wykorzystano refleks $\{200\}$. Stałe sprężyste obliczone dla tego refleksu zgodnie z modelem Reussa wynoszą $\mathrm{E}_{200}=66,69 \mathrm{GPa}$, $V_{200}=-0,419\left(E_{\text {bulk }}=109,32 \mathrm{GPa}\right)$. Do pomiarów naprężeń własnych w powłoce Ti wykorzystano refleks $\{101\}$. Stałe sprężyste obliczone dla tego refleksu zgodnie z modelem Reussa wynoszą: $E_{101}=125,9 \mathrm{GPa}, \mathrm{v}_{101}=-0,310\left(\mathrm{E}_{\text {bulk }}=129,83 \mathrm{GPa}\right)$. W tabeli 1 przedstawiono wyniki obliczonych naprężeń głównych $\left(\sigma_{1}, \sigma_{2}\right)$ oraz orientacji naprężenia głównego $\sigma_{1}$ badanej próbki względem krótszego boku próbki.
Tablica I. Wyniki klasycznej analizy stanu naprężeń własnych w powłoce $\mathrm{Cu}$ i Ti przy minimalizacji wpływu warstwy przypowierzchniowej materiału o grubości 2,0 $\mu \mathrm{m}$

Table I. Results of classical analysis of residual stresses in $\mathrm{Cu}$ and $\mathrm{Ti}$ coatings with minimization of the effect of $2,0 \mu \mathrm{m}$ subsurface layer

\begin{tabular}{|c|c|c|}
\hline Opis & Powłoka Cu & Powłoka Ti \\
\hline $\begin{array}{c}\text { Naprężenie własne } \sigma_{1} \\
(\mathrm{MPa})\end{array}$ & $87,0 \pm 9,0$ & $350,0 \pm 60,0$ \\
\hline $\begin{array}{c}\text { Naprężenie własne } \sigma_{2} \\
(\mathrm{MPa})\end{array}$ & $109,0 \pm 7,0$ & $192,0 \pm 55,0$ \\
\hline $\begin{array}{c}\text { Orientacja układu } \\
\text { naprężeń głównych } \sigma_{1} \\
\text { (względem krótszej } \\
\text { osi próbki) }\end{array}$ & $70,0^{\circ} \pm 18,0^{\circ}$ & $101,0^{\circ} \pm 15,0^{\circ}$ \\
\hline
\end{tabular}

Przedstawione wyniki pomiarów naprężeń własnych w analizowanych powłokach metalowych natryskiwanych na podłoże ceramiki $\mathrm{Al}_{2} \mathrm{O}_{3}$ pokazały, że we wszystkich badanych powłokach występują w płaszczyźnie powłoki naprężenia rozciągające. Wartości naprężeń są średnimi z głębokości wnikania wiązki tj. w granicach 20-30 $\mu \mathrm{m}$. W większości przypadków wyznaczone naprężenia główne $\sigma_{1}$ są zorientowane pod niewielkim kątem w stosunku do dłuższej osi próbek.

\section{Metoda interferometrii siatkowej (IS)}

Metoda interferometrii siatkowej doczekała się wielu systemów pomiarowych zróżnicowanych ze względu na przeznaczenie, czy zastosowane rozwiązania techniczne. Systemy takie umożliwiają uzyskanie map przemieszczeń i odkształceń w dwóch prostopadłych kierunkach analizy, a także podstawowych parametrów mechanicznych, tj. modułu Younga i współczynnika Poissona [6,7]. Systemy interferometrii siatkowej oferują stosunkowo niewielkie pole pomiarowe $(25 \times 25 \mathrm{~mm})$ ale dysponują bardzo wysoką czułością [8]. Dzięki temu metoda ta może być użyteczna do badania stanu przemieszczeń, odkształceń i naprężeń w natryskiwanych powłokach [9]. W tym kontekście podjęto badania z wykorzystaniem metody interferometrii siatkowej do pomiaru przemieszczeń oraz wyznaczenia naprężeń własnych w powłokach metalicznych natryskiwanych na podłoże ceramiczne. W celu oceny możliwości i przydatności tej metody jako alternatywnej do innych metod oceny stanu odkształceń i naprężeń w powłokach i warstwach przeprowadzono serię badań na próbkach z ceramiki $\mathrm{Al}_{2} \mathrm{O}_{3}$, na której natryśnięto metodą HVOF powłoki tytanowe i miedziane.

Metoda interferometrii siatkowej wymaga naniesienia dyfrakcyjnej siatki odbiciowej na płaską powierzchnię

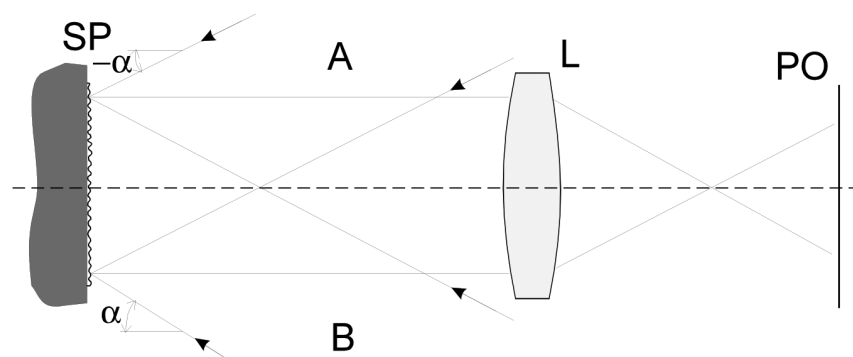

Rys. 1. Zasada działania interferometrii siatkowej: SP - siatka przedmiotowa naniesiona na badany element, L - układ odwzorowujący, PO - płaszczyzna obserwacji, A i B - wzajemnie koherentne wiązki oświetlające o płaskich frontach falowych, a - kąt ugięcia pierwszego rzędu dyfrakcyjnego siatki przedmiotowej

Fig. 1. The principle of operation of grating interferometry: SPspecimen grating, $L$ - imagine optics, $P O$ - detector plane, A,B mutually coherent wavefronts, $\mathrm{a}$ - first diffraction order angle 
badanego elementu. Siatka ta oświetlana jest następnie przez dwie wzajemnie koherentne wiązki o płaskich czołach falowych A i B (rys.3.1) [10].

Kąty padania tych wiązek są równe kątom ugięcia +1 i -1 rzędu dyfrakcyjnego siatki przedmiotowej. Przy spełnieniu tego warunku wiązki ugięte na siatce propagują się współosiowo wzdłuż normalnej do powierzchni badanego elementu. Przyłożone obciążenie powoduje odkształcenia badanego elementu, a co za tym idzie deformację linii nałożonej siatki dyfrakcyjnej. W efekcie, czoła falowe wiązek ugiętych na zdeformowanej siatce przestają być płaskie i niosą informację o przemieszczeniach w płaszczyźnie. Przemieszczenia płaszczyznowe $u(x, y)$ i $v(x, y)$ otrzymuje się stosując krzyżową siatkę przedmiotową o liniach równoległych odpowiednio do osi x i y. Układ interferometru powinien więc zapewniać dwie pary wiązek oświetlających próbkę we wzajemnie prostopadłych płaszczyznach padania. Realizowane jest to poprzez różnego typu układy podziału wiązki (głowica trójzwierciadlana, podwójny układ zwierciadeł Loyda, układ achromatycznego interferometru siatkowego, interferometr trójwiązkowy).

System laboratoryjnego interferometru siatkowego z trójzwierciadlaną głowicą 3M pokazano na rysunku 2. Światło $\mathrm{z}$ lasera He-Ne pada na kolimator $\mathrm{CO}$, a następnie po odbiciu się od zwierciadła M oświetla zwierciadła głowicy interferometru 3M. Po uformowaniu przez przysłonę dwóch par wiązek oświetlana jest symetrycznie w dwóch prostopadłych kierunkach krzyżowa siatka dyfrakcyjna. Każda para wiązek umożliwia pomiar składowej przemieszczeń u lub v w płaszczyźnie.

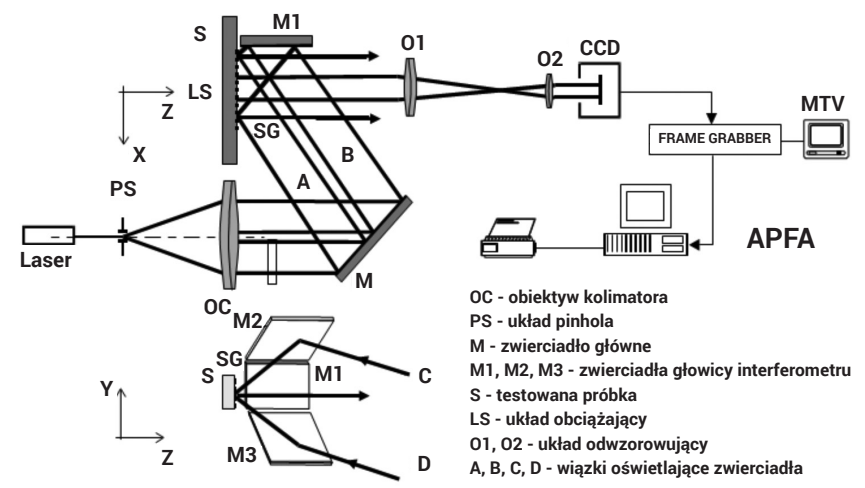

Rys. 2. Konfiguracja opto-mechanicznego, trójzwierciadlanego, laboratoryjnego systemu interferometru siatkowego

Fig. 2. Configuration of opto-mechanical, three-mirror four-beam grating interferometry measurement head

Czterowiązkowy interferometr siatkowy z głowicą trójzwierciadlaną umożliwia pomiar przemieszczeń na powierzchni badanej próbki w obu kierunkach, w maksymalnym polu pomiarowym 25 x $25 \mathrm{~mm}$ z dokładnością do $\lambda / 40$. Interferometr jest przystosowany do pracy z siatkami o częstości 1200 linii/ mm, których kąt ugięcia $+1,-1$ rzędu dyfrakcyjnego wynosi około $49^{\circ}$ przy oświetleniu wiązką lasera He-Ne o długości fali $\lambda=632,8 \mathrm{~nm}$. Stanowisko pomiarowe zapewnia bezdotykowy pomiar w całym polu pomiarowym (tu: o wymiarach $15 \times 15 \mathrm{~mm}$ lub mniejsze $z$ uwagi na zastosowany uchwyt do próbek) z rozdzielczością $512 \times 512$ pikseli.

Rejestrowane są szaroodcieniowe obrazy prążkowe o dynamice 256 poziomów szarości. Pomiar realizowany był przy zastosowaniu programu Fringe Application 2001 wyspecjalizowanego do pomiarów różnymi algorytmami za pomocą interferometrii siatkowej. Odkształcenia wyznaczono przez numeryczne różniczkowanie otrzymanych rozkładów przemieszczeń $u(x, y)$ i v $(x, y)$ według wzorów:

$\varepsilon_{\mathrm{xx}}=\frac{\partial u(\mathrm{x}, \mathrm{y})}{\partial \mathrm{x}} ; \varepsilon_{\mathrm{yy}}=\frac{\partial v(\mathrm{x}, \mathrm{y})}{\partial \mathrm{y}} ; \varepsilon_{\mathrm{xy}}=\frac{\partial u(\mathrm{x}, \mathrm{y})}{\partial \mathrm{x}}+\varepsilon_{\mathrm{yy}}=\frac{\partial v(\mathrm{x}, \mathrm{y})}{\partial \mathrm{y}}$
Natomiast naprężenia obliczano na podstawie związków między odkształceniami a naprężeniami (prawo Hooka).

$$
\sigma_{\mathrm{xx}}=\frac{E}{\left(1-v^{2}\right)}\left(\varepsilon_{\mathrm{xx}}+v \varepsilon_{\mathrm{yy}}\right)
$$

Pomiary przeprowadzono na próbce ceramicznej $\mathrm{Al}_{2} \mathrm{O}_{3}$ z natryskaną powłoką Ti oraz $\mathrm{Cu}$ za pomocą metody HVOF. Powłoka jest jednorodna na całej powierzchni próbki, średnia grubość powłoki Ti wynosiła 0,119 mm a powłoki Cu 0,085 $\mathrm{mm}$. Na powierzchnię powłoki naniesiono siatkę interferencyjną o rozdzielczości $1200 \mathrm{l} / \mathrm{mm}$ (rys. 4). Dokonano pomiaru siatki przez nacięciem powłoki oraz po nacięciu powłoki piłą beznaprężeniową w celu uwolnienia naprężeń. Nacięcie wykonano na głębokość naniesionej powłoki oraz w drugi etapie na głębokość ok. 1/3 ceramicznego podłoża. Pomiary siatki interfencyjnej prowadzono w dużym (ok. 14x14 mm) oraz w zmniejszonym polu pomiarowym (ok. 4x4 mm).

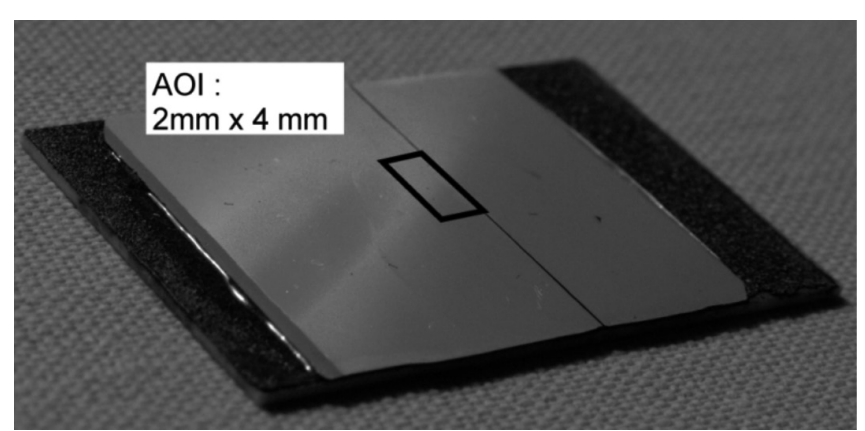

Rys. 3. Widok próbki z naniesioną na powłokę Ti siatką dyfrakcyjną oraz szczeliną po cięciu oraz zaznaczonym obszarem pomiarowym Fig. 3. Diffraction grating attached to the sample with Ti coatings, the cut line and marked measurement zone

Na rysunku 5 przedstawiono zestawienie wyników przekrojów przez mapy odkształceń $\varepsilon_{\mathrm{xx}}(\mathrm{x}, \mathrm{y})$ dla próbek z warstwami Cu oraz Ti (lewa strona przeciętych próbek). Najwyższe wartości odkształcenia występują na samej krawędzi szczeliny z uwagi na uwolnione tam w wyniku cięcia naprężenia. Widać wyraźnie, że w powłoce tytanowej odkształcenie osiągnęło znacznie wyższe wartości niż w powłoce miedzianej.

Składowa $\varepsilon_{\mathrm{yy}}(\mathrm{x}, \mathrm{y})$ odkształcenia jak pokazały wcześniejsze wyniki badań charakteryzowała się bardzo niewielkimi wartościami co wynikało wprost z kierunku cięcia, który uwolnił głównie naprężenia na kierunku x. Na rysunku 6a przedstawiono obliczony w oparciu o prawo Hooka rozkład naprężenia $\sigma_{\mathrm{xx}}$ $\mathrm{w}$ powłoce miedzianej po lewej i prawej stronie nacięcia.

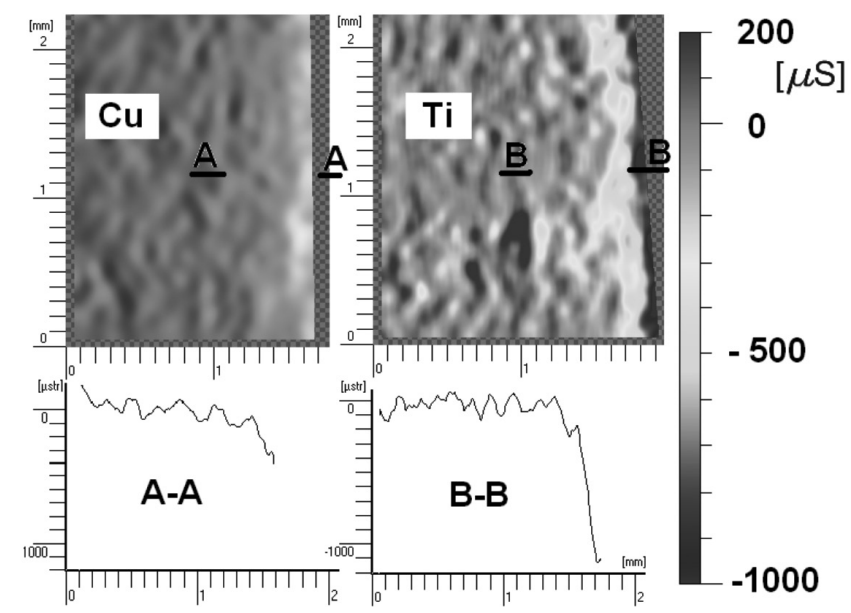

Rys. 5. Zestawienie wyników przekrojów przez mapy odkształceń $\varepsilon_{\mathrm{xx}}(\mathrm{x}, \mathrm{y})$ dla próbek z powłokami Cu oraz $\mathrm{Ti}$

Fig. 5. 2D maps of $\varepsilon_{x x}(x, y)$ strains calculated for the samples with $\mathrm{Cu}$ and Ti coatings after the cut and plots of the horizontal crosssections of strain maps 
Do obliczeń przyjęto wartość modułu Younga dla miedzi $\mathrm{E}=139,1 \mathrm{GPa}$. Najbardziej interesujący obszar występuje na krawędzi cięcia gdzie składowa odkształcenia $\varepsilon_{\mathrm{xx}}$ osiąga największe wartości. Jak widać z rysunku wzdłuż całej krawędzi ciętej próbki występują wahania wyznaczonego naprężenia.

W celu określenia średniej wielkości uwolnionego naprężenia dokonano uśrednienia wyników z interferometrii siatkowej z "ostatniej dostępnej“ pionowej linii mapy odkształceń $\varepsilon_{\mathrm{xx}}$ przy czy w obliczeniach odrzucono wyniki bardzo skrajne, głównie te z obszarów na początku i końcu linii cięcia. W ten sposób uzyskano wartość średnią naprężenia własnego w powłoce $z$ krawędzi cięcia wynoszącą $\sigma_{x x}=53,3 \pm 14 \mathrm{MPa}$.

a)
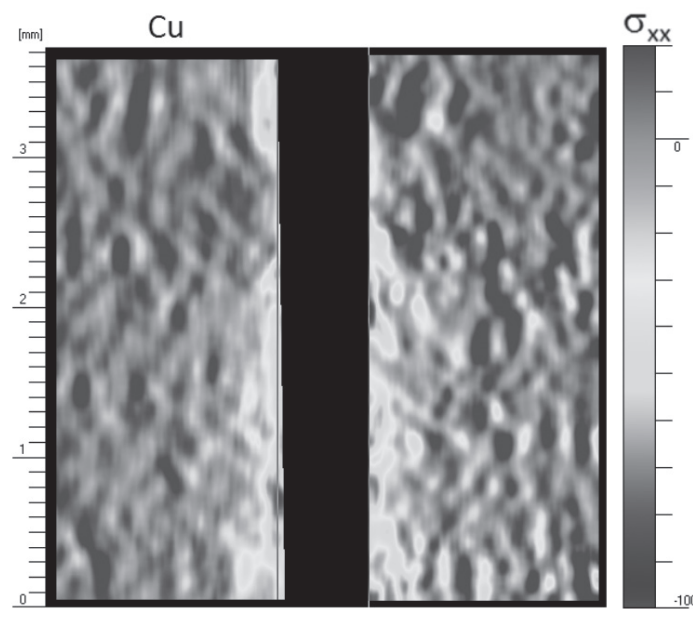

b)

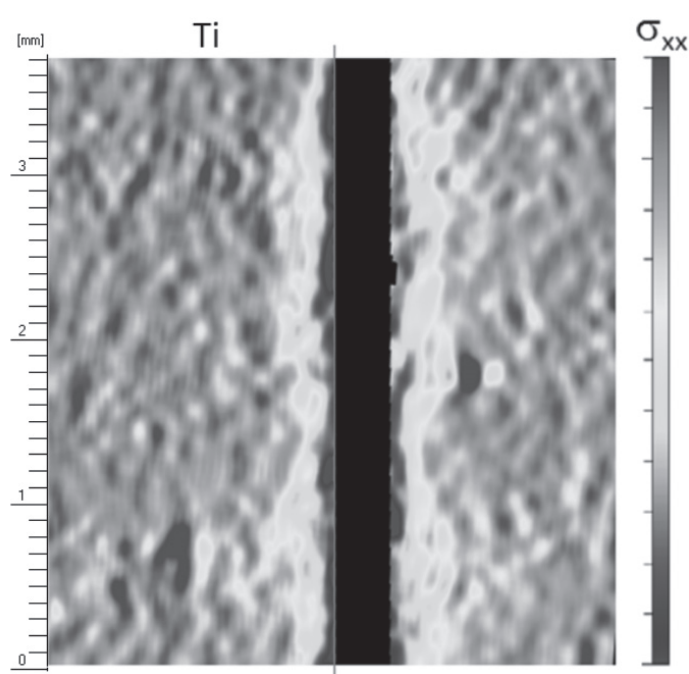

Rys. 6. Rozkład naprężenia $\sigma_{x x}$ wyznaczony w powłoce $C u$ i Ti próbki Fig. 6. $2 \mathrm{D}$ maps of calculated $\sigma_{\mathrm{xx}}$ residual stresses in $\mathrm{Cu}$ and $\mathrm{Ti}$ coatings

W podobny sposób dokonano obliczeń naprężenia własnego w powłoce tytanowej.

$\mathrm{Na}$ rysunku $6 \mathrm{~b}$ przedstawiono rozkład naprężeń $\sigma_{\mathrm{xx}}$ w powłoce Ti po dokonaniu jej przecięcia. Po uśrednieniu odkształceń z całej linii przechodzącej przez krawędź cięcia (256 punktów) otrzymano średnią wartość odkształcenia $\varepsilon_{\mathrm{xx}}=-930 \pm 113 \times 10-6$, na podstawie której wyznaczono średnie naprężenie własne w powłoce na krawędzi szczeliny $\sigma_{\mathrm{xx}}=120,7 \pm 14 \mathrm{MPa}$.

\section{Metoda krzywizny wygięcia}

Układ powłoka-podłoże możemy rozpatrywać jako połączenie dwóch płyt.

W wyniku różnego skurczu poprzecznego obu materiałów, powstającego w procesie ich chłodzenia powstaje pewne niedopasowanie płyt $\Delta \varepsilon$, przy czym układ sił poprzecznych musi być w równowadze dla całego układu. Efektem końcowym jest wygięcie płyt związane z powstającymi momentami gnącymi M i opisane krzywizną wygięcia $\mathrm{K}$.

W przypadku układu powłoka-podłoże wygięcie obu materiałów powstaje na skutek zróżnicowanego skurczu obu materiałów w czasie chłodzenia całego układu do temperatury otoczenia. Układ taki można traktować w pewnym sensie jako równoważny wygięciu płyt pod wpływem obciążenia go siłami i momentami gnącymi. Krzywiznę wygięcia (lub promień wygięcia) płyt można określić poprzez pomiar ugięcia płyt po procesie natryskiwania (rys.7). W zależności od różnicy współczynników rozszerzalności cieplnej powłoki i podłoża jego wygięcie może nastąpić w kierunku powłoki ( $a_{\text {powłoki }}<a_{\text {podłoża }}$ lub w kierunku podłoża gdy ( $\left.a_{\text {powłoki }}>a_{\text {podłoża }}\right)$.

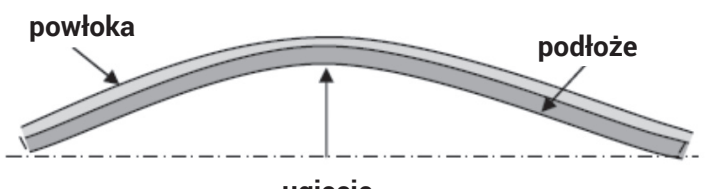

ugięcie

Rys. 7. Ugięcie podłoża z powłoką po natryskiwaniu

Fig. 7. Deflection of coating-substrate system after thermal spraying

W przypadku gdy grubość powłoki jest dużo mniejsza od grubości podłoża średnie naprężenie w powłoce można oszacować za pomocą równania Stoney'a [11]:

$$
\sigma_{d}=\frac{1}{6} \frac{E_{S}}{\left(1-v_{S}\right)} \frac{h^{2}}{H}\left(\frac{1}{R_{2}}-\frac{1}{R_{1}}\right)
$$

gdzie:

$\sigma_{d}$ - średnie naprężenie w powłoce,

$E_{s}$ - moduł Young'a dla podłoża,

$\mathrm{v}_{\mathrm{s}}$ - liczba Poissona dla podłoża,

h - grubość powłoki,

$H$ - grubość podłoża,

$R_{2}, R_{1}$ - promienie ugięcia odpowiednio po i przed natryskiem powłoki.

Jeśli warunek dużo niższej grubości powłoki od podłoża nie jest spełniony równanie to wprowadza pewien błąd. Clyne [12] opisał w sposób analityczny powyższy model uzyskując rozwiązanie umożliwiające wyznaczenie naprężeń na kierunku x w powłoce i podłożu przy założeniu, że w grubość powłoki nie jest dużo mniejsza od podłoża, oraz że w powłoce występuję dwuosiowy stan naprężenia. Modyfikując równanie Stoney'a otrzymał on rozwiązanie na podstawie którego oszacować można naprężenia w powłoce oraz w podłożu w charakterystycznych jej miejscach według poniższych równań:

- naprężenie na powierzchni górnej powłoki:

$$
\left.\sigma_{d}\right|_{y=h}=-\Delta \varepsilon\left(\frac{E_{d}^{\prime} H E_{s}^{\prime}}{h E_{d}^{\prime}+H E_{s}^{\prime}}\right)+E_{d}^{\prime} \kappa(h-\delta)
$$

- naprężenie na powierzchni dolnej powłoki:

$$
\left.\sigma_{d}\right|_{y=0}=-\Delta \varepsilon\left(\frac{E_{d}^{\prime} H E_{s}^{\prime}}{h E_{d}^{\prime}+H E_{s}^{\prime}}\right)-E_{d}^{\prime} \kappa \delta
$$

- naprężenie na powierzchni górnej podłoża:

$$
\left.\sigma_{s}\right|_{y=0}=\Delta \varepsilon\left(\frac{E_{d}^{\prime} H E_{s}^{\prime}}{h E_{d}^{\prime}+H E_{s}^{\prime}}\right)-E_{s}^{\prime} \kappa \delta
$$

- naprężenie na powierzchni dolnej podłoża:

$$
\left.\sigma_{s}\right|_{y=-H}=\Delta \varepsilon\left(\frac{E_{d}^{\prime} H E_{s}^{\prime}}{h E_{d}^{\prime}+H E_{s}^{\prime}}\right)-E_{s}^{\prime} \kappa(h+\delta)
$$


gdzie:

od,s - naprężenie w powłoce (d) i podłożu (s),

$\Delta \varepsilon=($ as-ad) $\Delta T$

ad,s - współczynnik rozszerzalności cieplnej powłoki

(d) i podłoża (s),

$\Delta \mathrm{T}$ - różnica temperatury,

, , zmodyfikowany moduł Younga,

h, $\mathrm{H}$ - grubości powłoki (h) i podłoża $(\mathrm{H})$,

Ed,s - moduł Younga powłoki (d), podłoża (s),

K - krzywizna wygięcia próbki (1/R),

$\delta$ - położenie osi obojętnej:

Mierząc wielkość wygięcia próbek s i korzystając z zależności geometrycznych danego układu powłoka-podłoże możliwe jest wyznaczenie krzywizny (promienia R) wygięcia K próbki, które umożliwia wyznaczenie naprężeń w oparciu o równania $(4 \div 7)$.

Do pomiaru ugięcia próbek po procesie natryskiwania zastosowano odpowiednio skonstruowany przyrząd pomiarowy składający się ze statywu, na którym zamocowany jest cyfrowy czujnik zegarowy oraz przestrzeni w której mocowana jest badana próbka. Próbka jest pozycjonowana przy pomocy kilku kołków ustalających oraz kołków które dociskają i unieruchamiają płytkę. Wskazanie czujnika zerowane było dla każdej płytki ceramicznej przed naniesieniem powłoki, a następnie rejestrowano ugięcie próbki z wraz powłoką nałożoną w procesie natryskiwania termicznego metodą HVOF.

Pomiary ugięcia prowadzono w dwóch seriach na 4 próbkach dla każdego z badanych materiałów powłokowych. W tablicy II zamieszczono wyniki pomiarów ugięcia próbek oraz zmierzone grubości powłok. Grubość podłoża ceramicznego $\mathrm{Al}_{2} \mathrm{O}_{3}$ wynosiła $0,59 \mathrm{~mm}$. Tuż po zakończonym natryskiwaniu mierzono temperaturę powierzchni powłok za pomocą pirometru w celu określenia temperatury początku chłodzenia utworzonej powłoki.

Dane z pomiaru grubości powłoki wskazują, że stosunek grubości powłoki do podłoża (od 12\% do 18,5\%) nie spełnia

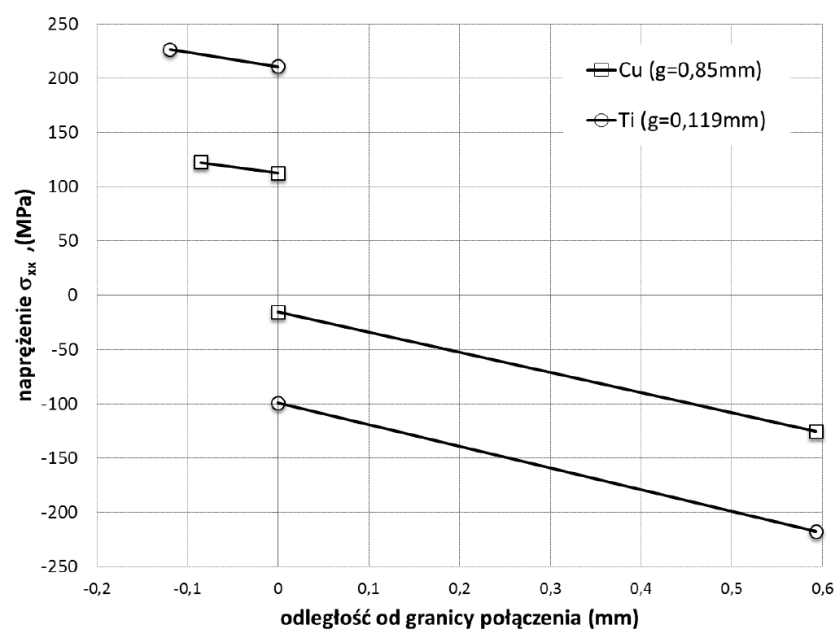

Rys. 8. Rozkład naprężeń własnych w układzie powłoka metalowapodłoże $\mathrm{Al}_{2} \mathrm{O}_{3}$ obliczony na podstawie krzywizny wygięcia próbek

Fig. 8. Distribution of residual stresses in metal coating- $\mathrm{Al}_{2} \mathrm{O}_{3}$ substrate system calculated based on the measurements of sample curvature warunku, dla którego powłoka jest traktowana jako dużo cieńsza od podłoża. Stąd, obliczenia naprężeń dla otrzymanych powłok przeprowadzono z wykorzystaniem zmodyfikowanego równania Stoney'a uwzględniającego wpływ

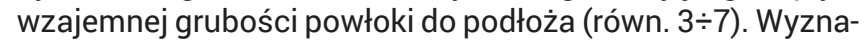
czone za pomocą równań $3 \div 7$ wartości naprężeń własnych w nanoszonych powłokach przedstawiono na wykresie na rysunek 8.

Jak widać z wykresu w powłoce występują naprężenia rozciągające przechodzące $w$ ceramice $w$ naprężenia ściskające. Na granicy połączenia widoczna jest skokowa zmiana naprężenia wywołana zróżnicowanym skurczem połączonych materiałów. W obrębie danego materiału powłokowego nie występują znaczące różnice w wartościach naprężeń w powłoce jak i w podłożu.

\section{Modelowanie naprężeń metodą elementów skończonych (MES)}

W zbudowanym modelu numerycznym przeprowadzono analizę termo-sprężysto-plastyczną, w wyniku której w próbce pozostały naprężenia własne $[13,14,15]$. Po wystudzeniu całego układu do temperatury otoczenia w modelu zasymulowano przecięcie, stosując opcję dezaktywacji elementów (element death), co spowodowało uwolnienie naprężeń wokół szczeliny i zmianę ugięcia układu. Model ze szczeliną z siatką MES oraz warunkami brzegowymi pokazano na rysunek 9.
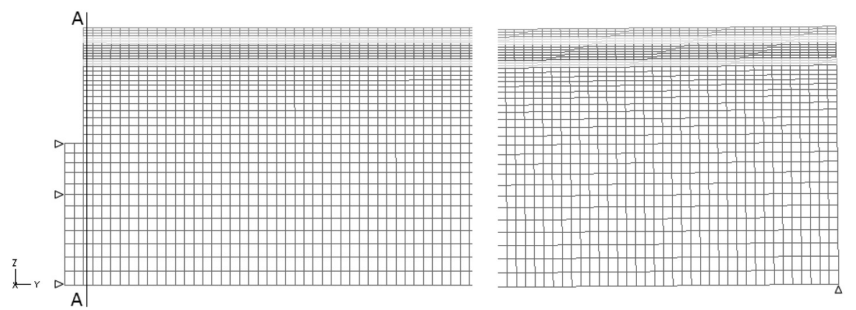

Rys. 9. Fragment siatki MES modelu ze szczeliną z oznaczeniem płaszczyzny przekroju

Fig. 9. Part of the finite element mesh with a cut

Na rysunku10 przedstawiono rozkłady naprężeń wzdłużnych $\sigma_{y y} w$ analizowanych układach ze szczeliną $i$ bez w postaci map naprężenia. W wyniku rozcięcia próbki na 1/3 grubości układu powłoka-podłoże nastąpiło uwolnienie naprężeń z granicy cięcia. Na rysunku 10b przedstawiono porównanie rozkładu przemieszczenia u w kierunku z na powierzchni powłoki Cu od krawędzi cięcia dla układu przed i po wykonaniu nacięcia.

Analogiczny rozkład dla składowej pionowej z przemieszczenia przedstawiono na rysunku 10c, który obrazuje linie ugięcia górnej powierzchni powłoki przed i po nacięciu. Widać wyraźnie, że nacięcie szczeliny spowodowało uwolnienie części naprężeń i zmniejszenie ugięcia próbki.

Widać to dokładnie na wykresie z rysunku 11 a gdzie zamieszczono rozkład naprężenia $\sigma_{y y}$ w przekroju poprzecznym układu powłoka-podłoże (przekrój A-A z rys. 9)

Tablica II. Wyniki zmierzonego ugięcia próbek z naniesionymi powłokami metalicznymi

Table II. Results of measured deflection of samples with metal coatings

\begin{tabular}{|c|c|c|c|c|c|c|}
\hline \multirow{2}{*}{ Powłoka } & \multicolumn{5}{|c|}{ Ugięcie próbki (mm) } & Średnie ugięcie \\
\cline { 2 - 7 } & 1 & 2 & 3 & 4 & $\begin{array}{c}\text { Średnia grubość } \\
\text { powłoki } \\
(\mathrm{mm})\end{array}$ \\
\hline $\mathrm{Cu}$ & 0,055 & 0,078 & 0,053 & 0,025 & 0,053 & 0,085 \\
\hline $\mathrm{Ti}$ & 0,088 & 0,063 & 0,052 & 0,053 & 0,064 & 0,119 \\
\hline
\end{tabular}


poprowadzony wzdłuż krawędzi szczeliny. Nastąpiło uwolnienie naprężeń w wyniku przecięcia materiału efektem czego naprężenie wzdłużne na powierzchni powłoki spadło do wartości bliskich zeru. Znacząco uległy obniżeniu naprężenia na granicy powłoka Cu-podłoże $\mathrm{Al}_{2} \mathrm{O}_{3}$ oraz w samym podłożu. W podobny sposób przeprowadzono modelowanie naprężeń w modelu z powłoką tytanową uzyskując podobne jakościowo wyniki. Na wykresie z rysunku $11 \mathrm{~b}$ przedstawiono rozkład naprężenia $\sigma_{y y} \mathrm{w}$ przekroju poprzecznym układu $\mathrm{Ti}^{-} \mathrm{Al}_{2} \mathrm{O}_{3}$ poprowadzony wzdłuż krawędzi szczeliny.

a) $\stackrel{z}{\perp}$

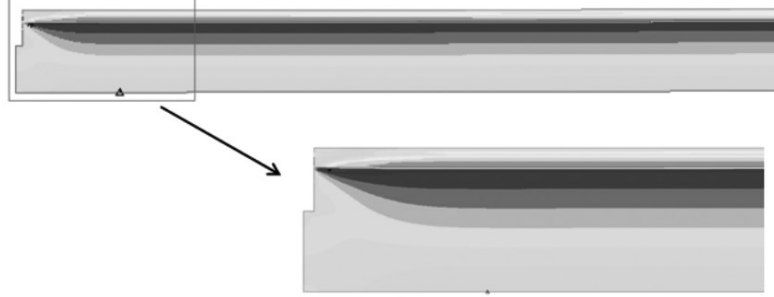

b)

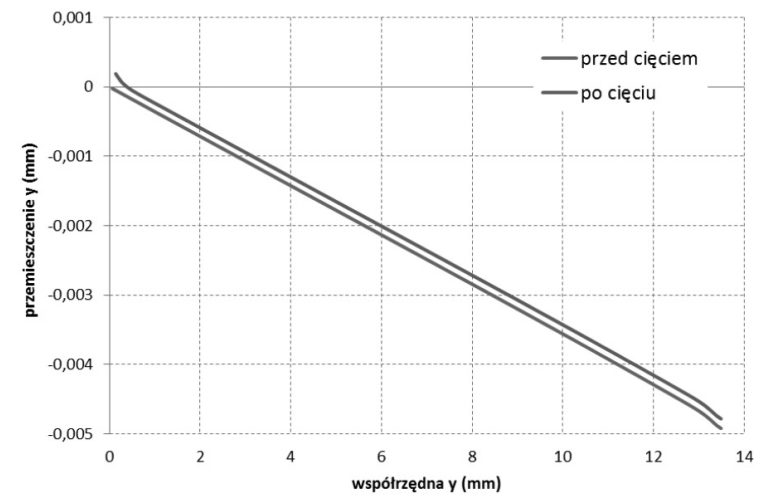

c)

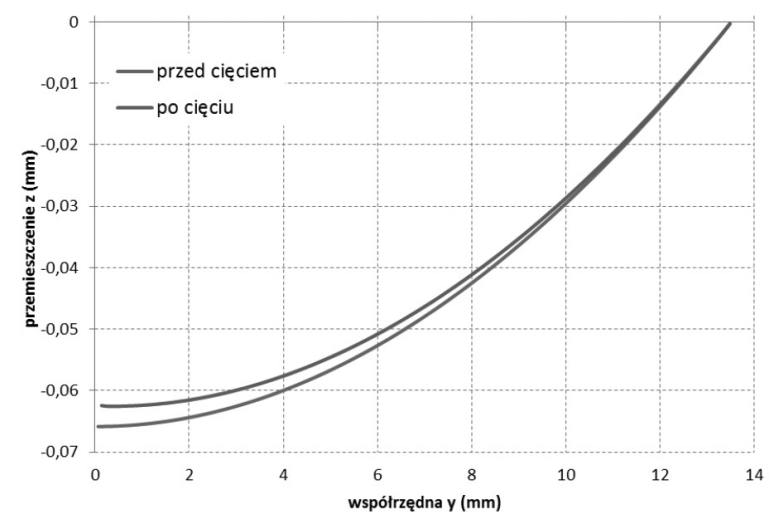

Rys. 10. Fragment siatki MES modelu ze szczeliną z oznaczeniem płaszczyzny przekroju

Fig. 10. Part of the finite element mesh with a cut

a)

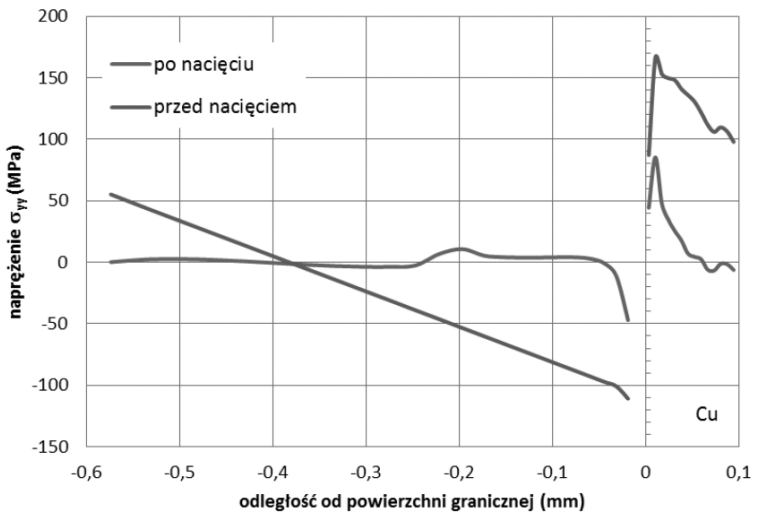

b)

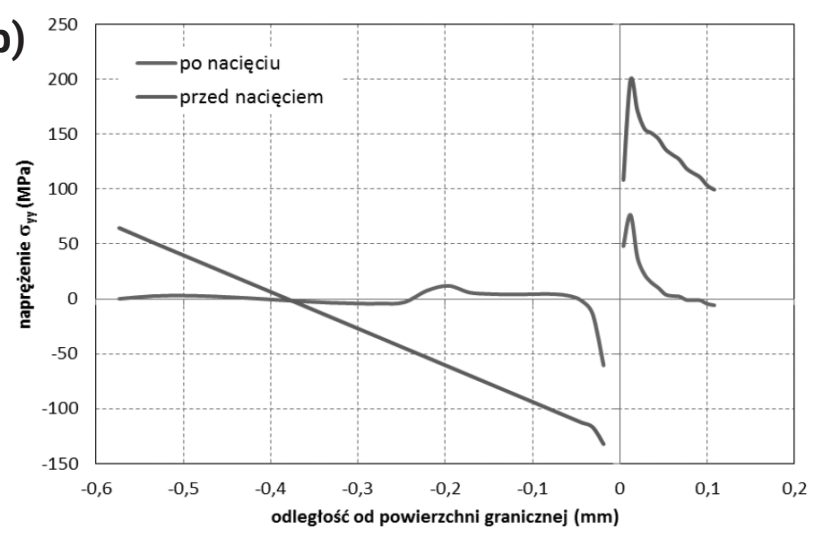

Rys. 11. Rozkład naprężeń $\sigma_{y y}$ w kierunku y w przekroju „A-A” przez model ze szczeliną i bez niej a) powłoka Cu, b) powłoka Ti

Fig. 11. Distribution of $\sigma_{y y}$ stresses at A-A cross line in model with and without the cut: a) Cu b) Ti coating

Tablica III. Naprężenia własne wyznaczone w powłokach Ti oraz Cu natryskiwanych na podłoże $\mathrm{Al}_{2} \mathrm{O}_{3}$

Table III. Residual stresses obtained in Ti and Cu coatings thermally sprayed on $\mathrm{Al}_{2} \mathrm{O}_{3}$ substrate

\begin{tabular}{|c|c|c|}
\hline \multicolumn{2}{|c|}{ Naprężenie własne } \\
\hline Metoda & Powłoka Ti & Powłoka Cu \\
\hline Metoda rentgenowska (X-ray) & $\begin{array}{c}\sigma_{1}=360 \pm 60 \mathrm{MPa} \\
\sigma_{2}=125 \pm 75 \mathrm{MPa}\end{array}$ & $\begin{array}{c}\sigma_{1}=87 \pm 9 \mathrm{MPa} \\
\sigma_{2}=109 \pm 7 \mathrm{MPa}\end{array}$ \\
\hline Pomiar ugięcia & $\sigma_{\mathrm{xx}}=229 \pm 12 \mathrm{MPa}$ & $\sigma_{\mathrm{xx}}=129 \pm 11 \mathrm{MPa}$ \\
\hline Interferometria siatkowa (IS) & $\sigma_{\mathrm{xx}}=151 \pm 14 \mathrm{MPa}$ & $\sigma_{\mathrm{xx}}=53 \pm 14 \mathrm{MPa}$ \\
\hline Modelowanie MES & $\sigma_{\mathrm{yy}}=198,8 \mathrm{MPa}$ & $\sigma_{\mathrm{yy}}=166,1 \mathrm{MPa}$ \\
\hline
\end{tabular}




\section{Podsumowanie}

Przeprowadzono porównanie naprężeń wyznaczonych przy użyciu interferometrii siatkowej (IS) z wynikami naprężeń otrzymanymi z badań rentgenowskich (X-ray), pomiarów z wykorzystaniem krzywizny wygięcia oraz modelu komputerowego. Wyniki naprężeń zamieszczono w tablicy III. Jak widać naprężenie główne podpowierzchniowe osiągnęło 360 MPa w powłoce Ti oraz 109 MPa w powłoce Cu według badań rentgenowskich. W tym przypadku kierunek naprężeń głównych nieznacznie odbiega od kierunku wzdłuż krawędzi próbki (x). Średnie naprężenie wyznaczone za pomocą interferometrii siatkowej jest nieznacznie niższe od wartości wyznaczonych w modelu MES dla powłoki Ti, natomiast większe niedoszacowanie wystąpiło dla powłoki $\mathrm{Cu}$, co mogło być efektem nie w pełni uwolnionych naprężeń w wyniku nacięcia próbki. Uzyskano rozciągające naprężenia własne w powłoce Ti w zakresie od 125 do 360 MPa, oraz w powłoce Cu od 53 do $166 \mathrm{MPa}$.

Przedstawione wyniki badań pokazują, że w zależności od zastosowanej metody badawczej stan naprężeń w powłokach pod względem ilościowym może różnić się między sobą natomiast rozkład naprężeń otrzymany w wyniku badań oraz modelowania numerycznego jest podobny. Badania przeprowadzone metodzie interfermetrii siatkowej wykazały obecność gradientu przemieszczenia/odkształenia w obszarze przy krawędzi nacinanego materiału wskazując na występowanie naprężeń w układzie powłoka-podłoże. Charakter tych zmian pokazuje, że wielkość naprężeń jest większa w powłoce Ti w porównaniu do powłoki Cu co potwierdziły pozostałe wyniki badań. Dalsze badania pola przemieszczeń, odkształceń i naprężeń, zawężone do krawędzi oraz bocznej powierzchni nacinanego materiału mogą umożliwić wyznaczenie zmian własności sprężystych powłoki i podłoża a także zintegrować metodą eksperymentalną z modelem numerycznym poprzez sprzężenie zwrotne.

Podziękowania: Praca finansowana z projektu NCN nr N N519 652840 oraz ze środków na działalność statutową w 2015 na Wydziale Inżynierii Produkcji, Zakład Inżynierii Spajania.

\section{Literatura}

[1] L. Pawlowski: The Science and Engineering of Thermal Spray Coatings. John Wiley \& Sons, Ltd, 2008.

[2] W. Wlosinski: The joining of advanced materials, The Publishing House of Warsaw University of Technology, 1999.

[3] B.H. Rabin, , R.L. Williamson and S. Suresh, Fundamentals of residual stresses in joints between dissimilar materials. MRS Bulletin, Jan. 1995, 37-39.

[4] P.Araujo, D.Chicot, M.Staia, J.Lesage: Residual stresses and adhesion of thermal spray coatings. Surface Engineering, vol.21 (2005), No.1, s. $35-40$.

[5] B. Kampfe: Investigation of residual stresses in microsystems using $X$-ray diffraction. Materials Science and Engineering A288 (2000) pp. 119-125.

[6] L. Salbut, M. Kujawinska, M. Jozwik, D. Golanski: Investigation of ceramic-to-metal joint properties by hybrid moire interferometry/FEM analysis. Proceedings of SPIE - The International Society for Optical Engineering, volume 3745 (1999), pp. 298-306.

[7] L. Salbut, M. Kujawinska, J. Bulhak, D. Golanski, A. Krajewski, Ceramicto-metal joints testing by automated grating interferometry, Experimental Mechanics, Allison (ed), Balkema, Rotterdam, 633-638, 1998.

[8] M. Kujawinska, Automated in-plane moiré techniques and grating interferometry in Optical methods in experimental solid mechanics, K-H. Laermann (ed), Springer Wien New York (2000), 123-196.
[9] J. Yi, X. Bin-shi, W. Hai-dou, L. Ming, L. Yao-hui, Determination of residual stresses within plasma spray coating using Moiré interferometry method. Applied Surface Science, 257(2011), pp. 2332-2336.

[10] D. Post, B. Han, P. Ifju, High Sensitivity Moiré, Springer-Verlag, 1994.

[11] G.G. Stoney,: The tension of metallic films deposited by electrolysis. Proceedings of the Royal Society (London) (1909) A82, pp.172-175.

[12] T.W. Clyne, S.C. Gill: Residual Stresses in Surface Coatings and Their Effects on Interfacial Debonding: A Review of Recent Work. J. Thermal Spray Technology, (1996), Vol. 5(4), pp. 401-418.

[13] J. Zimmerman, D. Golański, T. Chmielewski, W. Włosiński: Model obliczeniowy analizy naprężeń własnych w układzie powłoka-podłoże podczas nanoszenia powłok metodami termicznymi. Przegląd Spawalnictwa $\mathrm{Nr}$ 1/2013, s.12-16.

[14] D. Golański, T.Chmielewski, G. Gontarz, J. Zimmerman, W. Włosiński: Badania naprężeń własnych w powłokach natryskiwanych metodą HVOF. Przegląd Spawalnictwa, Nr 11/2013, s.30-35.

[15] J. Zimmerman, Z. Lindemann, D. Golanski, T. Chmielewski, W. Wlosinski: Modeling residual stresses generated in Ti coatings thermally sprayed on Al2O3 substrates. Bulletin of the Polish Academy of Sciences: Technical Sciences, vol. 61, Issue 2, (2013) pp. 515-525. 